\title{
Determination of crushing energy during vibratory crushing
}

\author{
Marcin Mazur \\ AGH University of Science and Technology, Poland
}

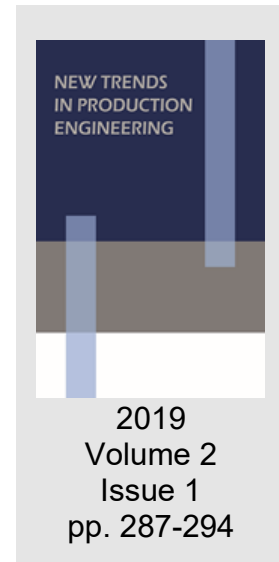

Date of submission to the Editor: 05/2019

Date of acceptance by the Editor: 07/2019

\section{INTRODUCTION}

The use of grained raw materials requires their proper mechanical processing (comminution, classification - screening, enrichment, granulation, etc.) (Feliks J., 2015; Gospodarczyk P., Kotwica K., Stopka G., 2013; Kotwica K., 2008; Mańczak K., 1976). In the mechanical processing basic and at the same time the most energy-consuming process is comminution (Ballantyne G. R., Powell M. S., 2014; Sidor J., Mazur M., 2015). This involves reducing size of the grain of material, referred to as the feed, by locally destroying the intermolecular cohesion (by exceeding the limit of its strength) as a result of external forces (Gupta A., Yan D., 2006), thus, it is related to the specific energy expended on the process of size reduction.

The problem of energy consumption during crushing or grinding, that is, determining the amount of energy required to reduce the size of mass unit of given material, is still not fully resolved. A number of hypotheses have been developed that attempt to describe energy-related phenomena occurring during comminution. Unfortunately, none of the today known theories fully describe this process. This is somewhat understandable due to the very large number of parameters (and their variability during the process) characterizing different materials subject to crushing, variable mechanisms for disintegrating material grains (depending on the type of load exerted), and finally the various types of machinery in which the process itself is carried out (crushers, mills).

One of the most widespread and widely used is the Bond's hypothesis (Bond F. C., 1952). One of the characteristic parameters used to determine energy of comminution is the particle size: $D 80$ - for feed and $d 80$ - for crushed product. These are easily determined by, for example, sieve analysis (or other methods of determining the grain size). The second parameter is the so-called crushing (grinding) Work Index - WI. This is the parameter that determines (approximately) the amount of energy needed to reduce size of the mass unit of material. Nevertheless, comminution processes occur with varying intensity 
depending on the material and machine used. Therefore, for each type of crushing or grinding, the work index must be separately designated (usually by standardized procedures). From the point of formal process analysis this is undoubtedly a disadvantage of this approach. On the other hand, from a practical point of view, this is a big advantage of this hypothesis. Work indexes are determined in laboratory conditions and then tabulated for different types of materials and comminution mechanisms (quasi-static or impact crushing, grinding, etc.). With this approach, Bond's hypothesis is now the most widely used theory of comminution in practical applications. The aim of the described study was to determine the value of Bond's work indexes (for limestone and diabase) during vibratory crushing.

\section{DESCRIPTION OF THE LABORATORY TEST STAND}

The energy consumption tests during vibratory crushing were carried out at a laboratory vibratory jaw crusher with kinematic actuation of vibrating jaws. The view of the test station is shown in Fig. 1.

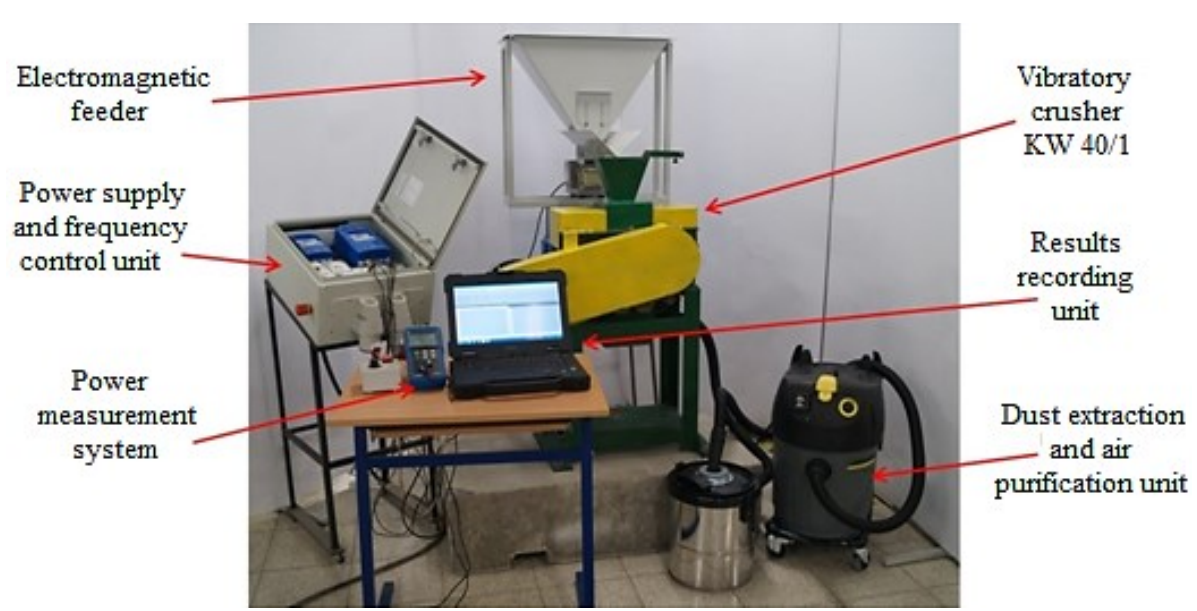

Fig. 1 View of the laboratory test station of the vibratory jaw crusher type KW 40/1 Source: (Mazur M, 2017)

The laboratory test station consists of a vibratory jaw crusher KW 40/1, a continuous feed delivery system in the form of an electromagnetic feeder, a power supply and frequency control unit (frequency inverter), an active power measuring system cooperating with a results recording computer and dust extraction and air purification unit. During the determination of the grain size distribution of the feed and the crushing product, a fully equipped sieve analyzer was used. In addition, the test station includes a set of gauge meters and other tools necessary to adjust work parameters of the crusher. The main part of the laboratory test station is the vibratory jaw crusher $\mathrm{KW} \mathrm{40/1,} \mathrm{which} \mathrm{is} \mathrm{shown} \mathrm{in}$ Fig. 2. The working unit of the KW 40/1 vibratory crusher shown in Fig. 2 consists of two moving jaws (1) pivotally mounted at the bottom. The recoil spring systems (4) press both jaws against the kinematic vibrator rollers (2). Both of the vibrator shafts are coupled by a chain transmission (5) driven by an electric motor (6). The movement of the jaws is opposed, that is, the jaws move synchronously at each moment in the "toward" or "away" direction. 


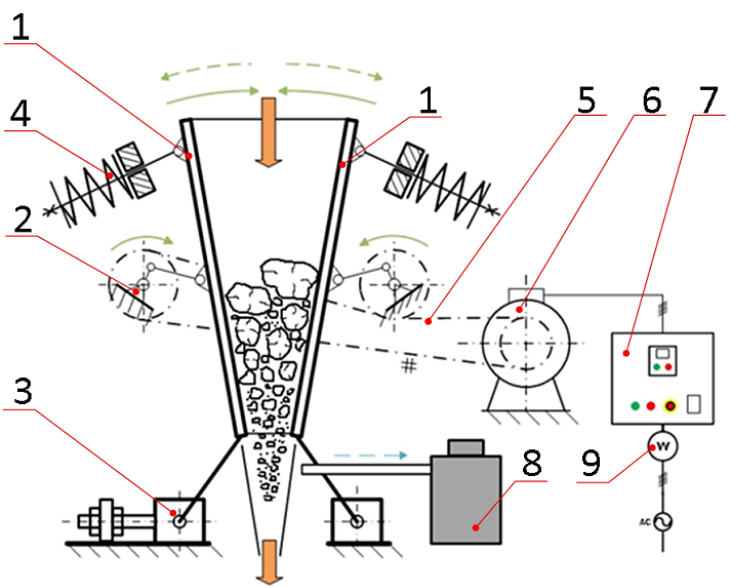

Fig. 2 Construction diagram of the laboratory vibratory jaw crusher type KW 40/1:

1-jaws, 2-kinematic vibrator, 3-outlet gap size adjustment mechanism, 4-recoil spring system, 5-chain transmission, 6-electric motor, 7-power supply and frequency control of crusher jaws, Source: (Mazur M, 2010) 8-dust extraction and air purification system, 9-active power meter

Synchronization of the jaw movement is provided by the chain transmission (5). The crusher has a design solution allowing adjusting the travel of both jaws. The vibration frequency control and power supply system (7) allows setting rotation speed of vibrator shafts, and thus the oscillation frequency of the jaws, and is also coupled with power measurement system (9) which allows recording the measurement results. Air purification and dust extraction from the crushing chamber is provided with industrial vacuum cleaner, in addition to the centrifugal filter (8).

For the study on vibratory crushing energy consumption two materials were used: limestone from "Czatkowice" mine in Krzeszowice, and diabase from "Niedźwiedzia Góra" mine in Tenczynek, Poland. Limestone is a sedimentary rock composed primarily of calcium carbonate, mainly in the form of calcite. The material from "Czatkowice" mine in Krzeszowice is characterized by high calcium carbonate content (above $96 \% \mathrm{CaCO}_{3}$ ), uniaxial compressive strength of $\sigma_{c}=90-150 \mathrm{MPa}$ and relatively high crystalline silica content (from 20 to $40 \%$ ). Diabase (another name dolerite) is a volcanic rock with a basalt mineral composition but with a thicker grain. The material from the "Niedźwiedzia Góra" mine in Tenczynek, is characterized by uniaxial compressive strength of $\sigma_{c}=$ 180-240 MPa. Each sample of the materials used for vibratory crushing tests had a mass of $2 \mathrm{~kg}$ and was compiled into samples of the same grain size distribution, shown in Table 1.

Table 1 Grain size distribution of individual samples used for vibratory crushing tests

\begin{tabular}{|c|c|c|c|c|c|}
\hline Material & $\begin{array}{c}\text { \% grain } \\
\text { class } \\
\mathbf{4 0} \div \mathbf{3 0} \mathbf{~ m m}\end{array}$ & $\begin{array}{c}\text { \% grain } \\
\text { class } \\
\mathbf{3 0} \div \mathbf{2 0} \mathbf{~ m m}\end{array}$ & $\begin{array}{c}\text { \% grain } \\
\text { class } \\
\mathbf{2 0} \div \mathbf{1 0} \mathbf{~ m m}\end{array}$ & $\begin{array}{c}\text { \% grain } \\
\text { class } \\
\mathbf{1 0} \div \mathbf{5} \mathbf{~ m m}\end{array}$ & $\begin{array}{c}\text { \% grain } \\
\text { class } \\
<\mathbf{5} \mathbf{~ m m}\end{array}$ \\
\hline Limestone/Diabase & 45.5 & 31.4 & 12.0 & 5.1 & 6.0 \\
\hline
\end{tabular}

\section{TEST METHOD AND RESULTS}

One of the main objectives of this study was to determine the experimental relation of the crushing energy consumption as a function of the construction 
parameters of the vibratory jaw crusher with the kinematic actuation of the jaws movement. As the construction parameters of the crusher, the following were assumed: jaw travel $-s$, outlet gap size - e, and frequency of jaws oscillation $\mathrm{f}$. Selected ranges of the crusher construction parameters during the tests, and also their specific values are shown in Table 2.

Table 2 Selected ranges of the KW 40/1 vibratory jaw crusher construction parameters, and their specific values used during tests

\begin{tabular}{|c|c|c|c|}
\hline Parameter & $\begin{array}{c}\text { Jaw travel } \\
{[\mathrm{mm}]}\end{array}$ & $\begin{array}{c}\text { Outlet gap size } \\
{[\mathrm{mm}]}\end{array}$ & $\begin{array}{c}\text { Frequency of jaws } \\
\text { oscillation } \\
{[\mathrm{Hz}]}\end{array}$ \\
\hline Range & $1.0 \div 9.0$ & $0.5 \div 10.0$ & $14 \div 22$ \\
\hline $\begin{array}{c}\text { Specific } \\
\text { values }\end{array}$ & $1.0,2.7,5.0,7.3,9.0$ & $0.5,2.5,5.25,8.0,10.0$ & $14,16,18,20,22$ \\
\hline
\end{tabular}

Due to a very large workload involved in the preparation of test materials, crushing tests for all combinations of crusher parameters and the required number of sieve analyzes, it was decided not to use the complete plan of experiment. Using the theory of experiment, it was decided to choose a plan of experiment that will meet basic criteria i.e. information, feasibility and efficiency (Mańczak K., 1976). Hence, the Hartley Plan labeled as PS/DS-P: Ha3 (hK) was adopted.

According to the test method, active power during crushing was measured, for each construction parameters combination defined by the experiment plan. On this basis, the specific crushing energy value $E_{j v}$ was determined in the process of vibratory crushing, calculated from the following relationship:

$$
E_{j v}=\frac{P_{K}}{Q} \quad[\mathrm{kWh} / \mathrm{Mg}]
$$

where:

$E_{j v}$ - specific energy of vibratory crushing, [kWh/Mg],

$P_{K}-$ active power during crushing, [kW],

$\mathrm{Q}$ - total efficiency (yield) [Mg/h].

After the sieve analysis, the values of $D 80$ and $d 80$ (characteristic grain size values) were read out from the grain size distribution curves of the feed and the crushing product. Then, from the available tables (Metso, 2015), the values of impact work index $W l_{l}$ for the tested materials were read out. For limestone this value was $W l_{l}=14 \pm 4 \mathrm{kWh} / \mathrm{Mg}$ while for diabase $W l_{l}=19 \pm 3 \mathrm{kWh} / \mathrm{Mg}$.

Then, knowing the size of the control grains $D 80$ and d80 as well as the value of the $W I_{l}$ indexes, the specific crushing energy $E_{j B v}$ for vibratory crushing was calculated for every construction parameters combination defined by the experiment plan. The following relationship, describing the Bond's hypothesis, was used:

where:

$$
E_{j B v}=10 \cdot W I_{I} \cdot\left(\frac{1}{\sqrt{d_{80}}}-\frac{1}{\sqrt{D_{80}}}\right)[\mathrm{kWh} / \mathrm{Mg}
$$

$E_{j B v}$ - specific energy of vibratory crushing calculated from the Bond's hypothesis, [kWh/Mg],

$W_{l}$ - Impact Work Index, [kWh/Mg], 
$D 80, d 80$ - control grain size respectively for the feed and the crushing product, $[\mu \mathrm{m}]$.

It was observed that the $E_{j B v}$ values calculated from the hypothesis differ considerably from the $E_{j v}$ values measured during the experiments. Results of the calculations, together with the values of specific crushing energy relative errors for the tested materials, are presented in Table 3.

Table 3 Results of the calculations and values of specific crushing energy relative errors for the tested materials

\begin{tabular}{|c|c|c|c|c|c|c|}
\hline Material & \multicolumn{3}{|c|}{ Limestone } & \multicolumn{3}{c|}{ Diabase } \\
\hline $\begin{array}{c}\text { Hartley } \\
\text { plan } \\
\text { layout }\end{array}$ & $\begin{array}{c}E_{j v} \\
\text { measured } \\
{[\mathrm{kWh} / \mathrm{Mg}]}\end{array}$ & $\begin{array}{c}E_{j B v} \\
\text { calculated } \\
(\text { Bond) } \\
{[\mathrm{kWh} / \mathrm{Mg}]}\end{array}$ & $\begin{array}{c}\text { Relative } \\
\text { error } \\
\delta \\
{[\%]}\end{array}$ & $\begin{array}{c}E_{j v} \\
\text { measured } \\
{[\mathrm{kWh} / \mathrm{Mg}]}\end{array}$ & $\begin{array}{c}E_{j B v} \\
\text { calculated } \\
(\text { Bond) } \\
{[\mathrm{kWh} / \mathrm{Mg}]}\end{array}$ & $\begin{array}{c}\text { Relative } \\
\text { error } \\
\delta \\
{[\%]}\end{array}$ \\
\hline 1 & 1.48 & 0.74 & 100.0 & 1.44 & 1.10 & 30.9 \\
\hline 2 & 2.03 & 1.26 & 61.1 & 3.15 & 1.89 & 66.7 \\
\hline 3 & 1.34 & 0.61 & 119.7 & 1.01 & 0.78 & 29.5 \\
\hline 4 & 2.82 & 1.77 & 59.3 & 3.12 & 2.39 & 30.5 \\
\hline 5 & 1.05 & 0.56 & 87.5 & 1.11 & 0.81 & 37.0 \\
\hline 6 & 1.42 & 0.70 & 102.9 & 1.46 & 1.04 & 40.9 \\
\hline 7 & 1.43 & 0.70 & 104.3 & 1.98 & 1.06 & 86.8 \\
\hline 8 & 1.29 & 0.70 & 84.3 & 1.33 & 1.02 & 30.4 \\
\hline 9 & 1.22 & 0.67 & 82.1 & 1.47 & 1.06 & 38.7 \\
\hline 10 & 1.52 & 0.72 & 111.1 & 1.38 & 1.03 & 34.0 \\
\hline 11 & 1.47 & 0.68 & 116.2 & 1.36 & 1.04 & 30.8 \\
\hline 12 & 2.22 & 1.29 & 72.1 & 2.63 & 1.90 & 38.4 \\
\hline 13 & 1.18 & 0.59 & 100.0 & 1.68 & 0.93 & 80.6 \\
\hline 14 & 1.34 & 0.77 & 74.0 & 1.73 & 1.20 & 44.2 \\
\hline
\end{tabular}

Source: (Mazur M, 2017)

Differences between the $E_{j v}$ values measured during the experiments, and the $E_{j B v}$ values calculated from the Bond Hypothesis is due to the fact that the $W I_{l}$ Work Index values, adopted for the calculation, do not accurately describe the specific crushing energy of the vibratory crushing process. For this reason, it was decided to calculate new values of $W I_{V}$ Work Indexes, which describe more precisely the process of vibratory crushing. For this purpose, the relationship (2) was transformed into the following form:

$$
W I_{V}=\frac{E_{j v}}{10 \cdot\left(\frac{1}{\sqrt{d_{80}}}-\frac{1}{\sqrt{D_{80}}}\right)} \quad[\mathrm{kWh} / \mathrm{Mg}]
$$

WIV - vibratory crushing Work Index, [kWh/Mg],

$E_{j v}$ - specific energy of vibratory crushing - measured, [kWh/Mg].

Results of calculations of the new WIV vibratory crushing Work Index are presented in Table 4.

Each of the calculated values of the vibratory crushing Work Indexes $W I_{V}$ were determined on the basis of two crushing tries, for each combination of crusher construction parameters defined by experiment plan. 
Table 4 Results of calculations of the new vibratory crushing Work Indexes WIV for limestone and diabase

\begin{tabular}{|c|c|c|c|c|c|c|}
\hline Material & \multicolumn{3}{|c|}{ Limestone } & \multicolumn{3}{|c|}{ Diabase } \\
\hline $\begin{array}{c}\text { Hartley } \\
\text { plan } \\
\text { layout }\end{array}$ & $\begin{array}{c}E_{j v} \\
\text { measured } \\
{[\mathrm{kWh} / \mathrm{Mg}} \\
]\end{array}$ & $\begin{array}{c}\text { Vibratory } \\
\text { Crushing } \\
\text { Work } \\
\text { Index } \\
W I_{V} \\
{[\mathrm{kWh} / \mathrm{Mg}]}\end{array}$ & $\begin{array}{c}\text { Vibratory } \\
\text { Crushing } \\
\text { Work } \\
\text { Index } \\
\text { (average) } \\
W I_{V} \\
{[\mathrm{kWh} / \mathrm{Mg}]}\end{array}$ & $\begin{array}{c}E_{j v} \\
\text { measured } \\
{[\mathrm{kWh} / \mathrm{Mg}]}\end{array}$ & $\begin{array}{c}\text { Vibratory } \\
\text { Crushing } \\
\text { Work } \\
\text { Index } \\
W I_{V} \\
{[\mathrm{kWh} / \mathrm{Mg}]}\end{array}$ & $\begin{array}{c}\text { Vibratory } \\
\text { Crushing } \\
\text { Work } \\
\text { Index } \\
\text { (average) } \\
W I_{V} \\
{[\mathrm{kWh} / \mathrm{Mg}]}\end{array}$ \\
\hline 1 & 1.48 & 23.9 & \multirow{14}{*}{$23 \pm 4$} & 1.44 & 24.8 & \multirow{14}{*}{$30 \pm 5$} \\
\hline 2 & 2.03 & 19.3 & & 3.15 & 30.6 & \\
\hline 3 & 1.34 & 26.5 & & 1.01 & 24.9 & \\
\hline 4 & 2.82 & 19.2 & & 3.12 & 24.8 & \\
\hline 5 & 1.05 & 22.6 & & 1.11 & 26.1 & \\
\hline 6 & 1.42 & 24.5 & & 1.46 & 26.6 & \\
\hline 7 & 1.43 & 24.5 & & 1.98 & 35.1 & \\
\hline 8 & 1.29 & 22.1 & & 1.33 & 24.7 & \\
\hline 9 & 1.22 & 21.8 & & 1.47 & 26,5 & \\
\hline 10 & 1.52 & 25.3 & & 1.38 & 25.5 & \\
\hline 11 & 1.47 & 26.1 & & 1.36 & 24.8 & \\
\hline 12 & 2.22 & 20.7 & & 2.63 & 26.3 & \\
\hline 13 & 1.18 & 24.1 & & 1.68 & 34.4 & \\
\hline 14 & 1.34 & 20.8 & & 1.73 & 27.5 & \\
\hline
\end{tabular}

Source: (Mazur M, 2017)

\section{CONCLUSSIONS}

As shown in Table 3, the $E_{j B v}$ values calculated from the hypothesis are considerably lower from the Ejv values measured during the experiments, for both tested materials. This is because the values of Impact Crushing Indexes $W l_{l}$ have been determined for other crushing conditions, during which there are no disintegration mechanisms characteristic for vibratory crushing. As shown in Table 4, the proposed Vibratory Crushing Work Indexes WIV are higher than available in literature (Metso, 2015; Gupta A., Yan D. 2006), for tested materials. This is strictly related to the intensity of the comminution process occurring in vibratory crushers. Considering character of the Bond's hypothesis, it can be seen that, as the difference between the characteristic values of the feed and the crushing product grain sizes ( $\mathrm{D}_{80}$ and $\mathrm{d}_{80}$ respectively) increases, the component in parentheses of equations number (3) and (4) $-\left(\frac{1}{\sqrt{d_{80}}}-\frac{1}{\sqrt{D_{80}}}\right)-$ also takes higher values, which (with the assumption of constant value of WI) leads to an increase in the calculated values of specific crushing energy $E_{j B}$. Bond's reasoning is most appropriate because, as is known from the theory of material strength (elasticity and plasticity theory), a load has to be applied to deform a material. Specifically, the larger deformation, the higher load must be applied to a body, and therefore the higher energy must be spent.

Crushing process (comminution in general) is an extreme case of exerting a strain on the material as internal cohesion forces are exceeded, which results in division of the grain into smaller parts, i.e. its fragmentation. It is correct to reason that the smaller the grains are after the division, the more energy is used for the process of this division. Hence the value of the expression $\left(\frac{1}{\sqrt{d_{80}}}-\frac{1}{\sqrt{D_{80}}}\right)$ determines how intensive the crushing process is and is closely related to the degree of fragmentation. In earlier works (Mazur M., 2010; Sidor J., Mazur M., 
2015; Tomach P., 2017a; Tomach P., 2017b) it has been shown that vibratory comminution is characterized by high degrees of fragmentation, i.e. a high degree of division of crushed material. For this reason, it can be concluded that the amount of energy transferred to the material during vibratory crushing (causing grain disintegration) will also be greater than in the other (quasi-static or impact) crushing processes. This reasoning explains the difference between the $E_{j B v}$ energy values calculated from the hypothesis and the $E_{j v}$ energy values measured during experiments. Hence, using aforementioned assumptions and the Bond's hypothesis, the new values of Vibratory Crushing Work Indexes $W I_{v}$ were calculated. Work Index, in general, provides information on the amount of energy that needs to be transferred to the mass unit of material to perform effective crushing process. The results of the study and the above-mentioned analysis show that the amount of energy spent on the crushing process in vibratory crushers, per unit of crushed material, is higher than in other crushing machines (due to the greater degree of grains fragmentation), so the values of Vibratory Crushing Work Indexes $W I_{V}$ should also be higher than those described in the literature. And so it is in fact.

\section{REFERENCES}

Ballantyne G. R., Powell M. S.: Benchmarking comminution energy consumption for the processing of copper and gold ores, Minerals Engineering, 2014, vol. 65, s. 109114.

Basics in Minerals Processing. Handbook, Metso Minerals, 2015.

Bond F. C.: The third theory of comminution. Mining Engineering, vol. 5, s. 484-494, 1952

Feliks J.: Granulation of dolomite and limestone in the vibratory granulator, Przemysł Chemiczny, t. 94, nr 5, p. 771-773, 2015.

Gospodarczyk P., Kotwica K., Stopka G.: A new generation mining head with disc tool of complex trajectory - Głowica urabiająca nowej generacji z narzędziami dyskowymi o złożonej trajektorii Archives of Mining Sciences - Archiwum Górnictwa, vol. 58 t. 4 p. 985-1006, 2013.

Gupta A., Yan D.: Mineral Processing Design and Operation, Elsevier Science, 2006.

Kotwica K.: Scenarios of technological development of roadways mining in Polish coal mines conditions. Mineral Resources Management, Tom 24, Zeszyt 1/2, Wydawnictwo IGSMiE PAN Kraków, p. 139-153, Kraków 2008.

Mazur M.: Examination of quartzite and diabase vibratory crushing .Materials of Polish Conference of Young Scientists, Kraków, vol. 5, p. 93-101, 2010.

Mazur M.: Research of crushing efficiency in vibratory jaw crushers, Doctoral thesis, AGH University of Science and Technology, Unpublished, 2017.

Mańczak K.: Technika planowania eksperymentu - Experimental planning techniques, Wydawnictwo Naukowo Techniczne, Warszawa, 1976.

Mendyka P., Kotwica K., Stopka G., Gospodarczyk P.: Innovative roadheader mining head with asymmetrical disc tools. International multidisciplinary scientific geoconference: science and technologies in geology, exploration and mining: 30 June-6 July, 2016, Albena, Bulgaria: conference proceedings. Vol. 2, Exploration and mining, mineral processing. - Sofia: STEF92 Technology Ltd., cop. 2016, s.489-496, 2016.

Sidor J., Mazur M.: Comparative studies of vibratory crushing process performed in jaw crushers, Ceramic Materials, ISSN: 1505-1269. t. 67 nr 1, p. 62-66, 2015. 
Tomach, P.: The process model of the vibratory mill including the impact of the milling process-intensifying element [in Polish]. Przemysł Chemiczny, ISSN 0033-2496, Vol. 96 No. 12, pp. 2467-2470, 2017 a.

Tomach, P.: Study of intensification of the milling process in the vibratory mill [in Polish]. Przemysł Chemiczny, ISSN 0033-2496, Vol. 96 No. 9, pp. 1893-1897, 2017b.

\begin{abstract}
.
The paper presents a new method of determining the energy consumption for vibratory crushing. Using the laboratory vibratory jaw crusher with kinematic actuation of the jaws, the study of determining power consumption while crushing limestone and diabase was conducted. During the study, electrical energy used on the crushing process was measured as a function of changing design and kinematic parameters of the vibratory crusher, i.e.: jaws stroke, the outlet gap size and frequency of jaws vibration. The article presents program of the research, the laboratory test stand of the vibratory jaw crusher KW 40/1 and the test results. Comparing the theoretical crushing energy requirements, determined by the Bond hypothesis, with the values measured during tests a large differences were observed. Using the Bond hypothesis the Vibratory Work Indexes were determined for the tested materials. Their values are higher than limestone and diabase Work Indexes available in the known literatures. The explanation may be greater amount of energy transferred to the material during vibratory crushing, which results in much higher efficiency of the crushing process.
\end{abstract}

Keywords: crushing, vibratory crushing, crushing energy 